\title{
Conexão Repórter no YouTube: o discurso dos internautas sobre o caso do jogador Daniel
}

\section{Conexão Repórter on YouTube: Internet users' discourse on Daniel's case \\ Conexão Repórter en YouTube: discurso de los usuários de Internet sobre el caso de Daniel}

\author{
Carlos Golembiewski \\ Pontifícia Universidade Católica do Rio Grande do Sul - UNIVALI \\ ORCID: https://orcid.org/0000-0002-5647-6118 \\ Endereço currículo Plataforma Lattes: http://lattes.cnpq.br/6029341241030720 \\ E-mail: carlosinterligado@yahoo.com.br \\ Eduardo Henrique Olschowsky Christóvão \\ Pontifícia Universidade Católica do Rio Grande do Sul - UNIVALI \\ E-mail: eduardoolschowsky@hotmail.com
}

Resumo: A pesquisa revela o discurso dos internautas que assistiram à edição do Conexão Repórter (SBT) sobre o caso Daniel, disponibilizado no YouTube pelo canal oficial do programa. Daniel era jogador de futebol e foi assassinato brutalmente em 28 de outubro de 2018, na cidade de São José dos Pinhais, no Paraná. A edição do programa traz uma entrevista exclusiva com Allana Brites, filha do casal acusado de ter praticado o crime. Para analisar o que os internautas disseram sobre a Entrevista, a pesquisa compilou os últimos 100 comentários postados no Youtube sobre o tema. A coleta foi realizada no dia 18 de setembro de 2019. A metodologia usada na pesquisa foi o Discurso do Sujeito Coletivo (DSC), criada por Lefevre \& Lefevre (2006), que propõe que, quando várias pessoas falam sobre um mesmo assunto, ocorre o chamado Discurso Coletivo. Entre as conclusões, pode-se dizer que grande parte dos internautas fizeram um linchamento público da Allana, criticaram a justiça e elogiaram o programa comandado pelo jornalista Roberto Cabrini.

Palavras-chave: Conexão Repórter. Caso Daniel. Discurso do Sujeito Coletivo. Internautas. SBT - Sistema Brasileiro de Televisão.

\begin{abstract}
The research reveals the speech of the Internet users who watched the edition of Conexão Repórter (SBT) about the Daniel case, made available on YouTube by the official channel of the program. Daniel was a football player and was brutally murdered on October
\end{abstract}


28, 2018, in the city of São José dos Pinhais, Paraná. The program edition features an exclusive interview with Allana Brites, daughter of the couple accused of having committed the crime. To analyze what netizens said about the Interview, the survey compiled the last 100 comments posted on YouTube on the topic. The collection was carried out on September 18, 2019. The methodology used in the research was the Collective Subject Discourse (DSC), created by Lefevre \& Lefevre (2006), who proposes that, when several people talk about the same subject, it occurs the so-called Collective Discourse. Among the conclusions, it can be said that most Internet users publicly lynched Allana, criticized justice and praised the program led by journalist Roberto Cabrini.

Keywords: Conexão Repórter. Daniel case. Collective Subject Discourse. Internet users. SBT - Sistema Brasileiro de Televisão.

Resumen: La investigación revela el discurso de los usuarios de Internet que vieron la edición de Conexão Repórter (SBT) sobre el caso de Daniel, puesto a disposición en YouTube por el canal oficial del programa. Daniel era jugador de fútbol y fue brutalmente asesinado el 28 de octubre de 2018 en la ciudad de São José dos Pinhais, Paraná. La edición del programa presenta una entrevista exclusiva con Allana Brites, hija de la pareja acusada de haber cometido el crimen. Para analizar lo que dijeron los internautas sobre la entrevista, la encuesta compiló los últimos 100 comentarios publicados en Youtube sobre el tema. La colección se llevó a cabo el 18 de septiembre de 2019. La metodología utilizada en la investigación fue el Discurso del Sujeto Colectivo (DSC), creado por Lefevre y Lefevre (2006), quien propone que, cuando varias personas hablan sobre el mismo tema, ocurre el llamado discurso colectivo. Entre las conclusiones, se puede decir que la mayoría de los usuarios de Internet lincharon públicamente a Allana, criticaron el sistema de justicia y elogiaron el programa dirigido por el periodista Roberto Cabrini.

Palabras clave: Conexão Repórter. Caso Daniel. Discurso del sujeto colectivo. Usuarios de internet. SBT - Sistema Brasileiro de Televisão.

\section{INTRODUÇÃO}

O vídeo intitulado "Allana Fala" disponibilizado no canal oficial do Conexão Repórter, no YouTube, acumulou 975.255 visualizações. Foi ao ar no dia 13 de agosto de 2019, porém, o programa passou na televisão no dia anterior. O episódio de $54 \min 55 \mathrm{~s}$., traz uma entrevista exclusiva com Allana Brittes, 18 anos, a primeira que concedeu desde 
que recebeu o habeas corpus em 6 de agosto de 2019 (BRITTES, 2019). Ela é acusada de ter participado do crime que matou o jogador de futebol Daniel, que na época atuava no São Paulo Futebol Club, um dos principais clubes de futebol do Brasil.

Exibido às segundas-feiras às $23 \mathrm{~h} 30$ pelo Sistema Brasileiro de Televisão (SBT), o Conexão Repórter tem como objetivo a busca pela verdade através de grandes reportagens. O programa defende a bandeira da exclusividade. Seu nome, "Conexão" indica a velocidade crescente das conexões por onde passa a informação, "Repórter" é usado para indicar o formato jornalístico (SBT, 2019).

A opção por estudar o caso que envolveu o jogador Daniel é justamente a polêmica e as diferentes formas de analisar que o público pode ter, de certa forma, o suposto anonimato da internet, somado a assuntos que provoquem os valores pessoais da audiência, acabaram sendo a centelha de uma discussão acalorada entre os internautas. A escolha do programa, vem da própria "linha editorial", lugar que privilegia esse tipo de tema e abordagem. Além disso, essa entrevista tinha o apelo de ser, a primeira concedida a uma emissora de TV, desde que Allana saiu da prisão, no qual foram reveladas informações exclusivas.

O programa que está no ar desde 2010, criou seu canal no YouTube em 27 de maio de 2014. No dia 13 de agosto de 2019, o SBT informou através de seu site que o canal acabara de atingir o primeiro milhão de inscritos na plataforma (SBT, 2019). O editor-chefe e apresentador do Conexão Repórter, Francisco Roberto Cabrini popularmente conhecido como Cabrini, nasceu em 3 de outubro de 1960, no município de Piracicaba, localizado no interior do estado de São Paulo. Cabrini começou sua carreira durante o ensino médio na editoria de esporte da rádio A Voz Agrícola e no Jornal do Povo. No final do segundo ano do ensino médio, o repórter fez um teste e passou a trabalhar na Rede Globo (MEMÓRIA GLOBO, 2019).

Para Souza (2015, p. 148), a principal característica que diferencia o formato de programa "Entrevista" dos demais, está ligado à cenografia. Nesse tipo de programa, o apresentador e os convidados devem estar sentados, simbolicamente, isso significa ao espectador que a entrevista será mais longa. No talk show, é comum que a cenografia seja feita com o intuito de permitir a liberdade do apresentador, para que possa interagir com os convidados e demais elementos do programa. Outra característica apontada por 
Souza (2015) é que no programa de Entrevista a estrela é o convidado e não o apresentador como ocorre nos talk shows.

O objetivo deste artigo é revelar a opinião dos internautas do YouTube sobre a entrevista de Allana dada ao jornalista Roberto Cabrini, no programa Conexão Repórter do SBT, sobre o crime chamado pela imprensa de "caso Daniel". Dos 100 comentários coletados, dez foram descartados, pois não se encaixavam na proposta da pesquisa. Portanto, o problema de pesquisa é: Qual é a opinião dos internautas que assistiram a entrevista de Allana Brites concedida ao programa Profissão Conexão Repórter do SBT?

Essa pesquisa se justifica por vários estudos que têm sido feitos sobre o consumo da informação nas redes sociais. Um deles, noticiado pelo Observatório da Imprensa em 2015, realizado pela ONG americana, American Press Institute, com os millenials, geração entre 18 e 34 anos, revelou que 90\% dos jovens americanos consomem notícias através do Facebook. E, que elas não são procuradas, mas encontradas acidentalmente quando se navega na rede. A pesquisa também concluiu que essa geração usa motores de busca e agregadores de notícias, para buscar informações complementares, dessa forma, opta por ficar no conteúdo que lhes inspire mais confiança e profissionalismo (OBSERVATÓRIO DA IMPRENSA, 2015).

Dentre essas preferências de busca, em primeiro lugar ficam as redes socais, em segundo lugar ficam os agregadores de notícias e os sites de buscas e, em terceiro lugar vem a mídia tradicional, que além de ser constantemente compartilhada pelas redes sociais, ainda é acessada diretamente por consumidores jovens.

Negroponte (1995, p. 175), professor no Massachusetts Institute of Technology (MIT), escreve sobre a rede em seu livro "A vida digital": "Ela (a rede) está criando um tecido social inteiramente novo e global. Prossegue o autor (1995, p. 164): “O 'nobre’ do horário nobre será a nossa opinião sobre ele, e não aquela de uma massa demográfica e abstrata de potenciais consumidores de um novo carro de luxo ou detergente para máquina de lavar pratos". É por isso que essa pesquisa que revela a opinião dos internautas sobre uma entrevista concedida ao programa Conexão Repórter, se justifica. 


\section{METODOLOGIA}

A metodologia usada nesta pesquisa foi o Discurso do Sujeito Coletivo (DSC). Segundo os criadores, o DSC é a construção de um discurso coletivo, que opina na primeira pessoa do singular (LEFEVRE, LEFEVRE, 2006). No caso deste trabalho, os relatos que formaram o Discurso do Sujeito Coletivo foram retirados da plataforma de vídeos YouTube.

Para a realização da pesquisa, foram extraídos os 100 últimos comentários do vídeo: “Allana Fala - Completo | Conexão Repórter (12/08/19)" postados no canal oficial do Conexão Repórter no YouTube, a partir do dia 13 de agosto de 2019. A coleta foi feita no dia 18/09/19 às 12 h 48 min. Comentários com caráter unicamente ofensivo e sem opinião alguma foram descartados.

Assim, 10 dos 100 comentários não puderam ser categorizados na abordagem definida, esses foram classificados como outros e não foram analisados. As categorias que surgiram foram as seguintes: Allana, Crime e Conexão Repórter/Roberto Cabrini. Dentro de cada uma, as opiniões dos internautas revelaram respectivamente: a imagem da entrevistada após o programa; quem é considerado o maior culpado do crime; e, como os espectadores enxergaram a qualidade jornalística do programa analisado.

Os 90 comentários selecionados formaram o que os autores do DSC chamam de "Expressões Chave" (ECH). Depois, desse pequeno texto é retirada a ideia central (IC) que indica a essência do comentário feito pelo internauta. A soma de todas essas ideias centrais sobre um mesmo assunto forma o chamado Discurso do Sujeito Coletivo (FIGUEIREDO, CHIARI, GOULART, 2013).

\section{A CURTA CARREIRA DO JOGADOR "DANIEL"}

A primeira oportunidade para Daniel mostrar seu talento foi nas categorias de base do Cruzeiro, em 2009. Clube do qual sairia quatro anos depois, em 2013, por desacordos comerciais, porém, nesse mesmo ano, o atleta foi o camisa 10 do time na Copa São de Futebol Júnior de 2013. Ainda em 2013, o futebolista seria contratado pelo Botafogo para jogar na sub-20, mas jogaria apenas uma partida devido às lesões que precisaram de tempo para serem curadas (BOTTA et al., 2018). 
Em 2014, o jogador ganhou destaque ao participar uma goleada de 6 a 0 contra o Criciúma, jogo do qual marcou metade dos gols. Em setembro daquele ano, o atleta, que chegou a ser chamado de "Messi" pelos companheiros de equipe, sofre uma lesão no ligamento do joelho direito durante um jogo contra o Ceará, que seria resolvida com uma cirurgia. Depois de 29 jogos defendendo a organização alvinegra, em dezembro, Daniel deixa o Botafogo por causa do atraso do salário (BOTTA et al.,2018).

Em 2015, após conseguir se desvincular do Botafogo, via Justiça, e mesmo estando em fase de recuperação, Daniel seria contratado pelo São Paulo, clube que jogaria 16 jogos entre 2015 e 2016 sem marcar nenhum gol. Com a queda no rendimento em campo, o atleta foi emprestado para diferentes clubes entre 2017 e 2018. O primeiro empréstimo foi feito para o Coritiba, clube em que o jogador ficou muito tempo no departamento médico, jogou apenas 6 partidas e não marcou nenhum gol (BOTTA et al.,2018).

A segunda equipe a possuir o jogador em sua linha de frente foi a Ponte Preta, que abrigaria Daniel durante 4 meses. Foram 10 jogos, muitos problemas físicos e o jogador seria devolvido após o Campeonato Paulista. Em junho de 2018, com contrato firmado até o final do ano com o São Paulo Futebol Clube, Daniel chega ao São Bento, time da série B. Nos quatro meses que ficou no clube, o jogador pode jogar apenas 39 minutos, antes de ser atrapalhado por seu problema crônico no joelho (BOTTA et al., 2018). Dois meses depois da partida que se machucou, o meia seria liberado para passar um final de semana no Paraná, onde iria a uma festa com amigos que fez durante a estadia no Coritiba (MELLO, 2018).

\subsection{O caso Daniel}

No sábado, dia 28 de outubro de 2018, aos 24 anos de idade, o corpo do exjogador de futebol, Daniel Corrêa Freitas, foi encontrado na Colônia Mergulhão, em São José dos Pinhais, cidade da região metropolitana de Curitiba, com o pescoço parcialmente degolado e o pênis decepado. O cadáver de Daniel foi localizado graças as marcas de sangue encontradas por um morador, que seguiu no encalço até encontrá-lo, o corpo vestia apenas uma camiseta e havia sinais de tortura (RIC MAIS, 2019a).

Daniel foi ao Shed Western Bar, dia 27 de outubro, no bairro Batel na capital paranaense, Curitiba, para prestigiar o aniversário de 18 anos de Allana Brittes. Segundo a casa noturna, o futebolista não se envolveu em nenhuma confusão durante a 
comemoração. As investigações revelaram ainda que aconteceu um after party no salão de festas na casa de Allana. Às $8 \mathrm{~h} 18 \mathrm{~min}$., do dia seguinte, o jogador enviou uma foto para um amigo, em que está deitado ao lado de Cristiana Brittes, mãe de Allana e mulher de Edison Brittes. Em mensagens enviadas minutos depois, o jogador afirma ter feito sexo com Cristiana (RICMAIS, 2019b).

No dia 29 de outubro, Edison, Allana e Cristiana almoçaram juntos com mais três homens em um shopping, momento em que combinam a história que viria a ser contada no primeiro depoimento. Nessa versão, Daniel teria saído da festa sozinho durante a noite do dia 27. Entretanto, no dia31 de outubro, uma testemunha admitiu que o ex-jogador foi espancado antes do assassinato (VEJA, 2019a).

No dia seguinte, Edison Brittes se entrega para a polícia e confessa ter matado o jogador. Ele afirmou que Daniel foi apanhado em seu quarto tentando abusar sexualmente de sua esposa. Segundo o advogado de defesa da família, Claudio Dalledone, a intenção não era de assassinar Daniel, e sim largá-lo em na área rural de São José dos Pinhais. Porém, durante o trajeto, o celular do jogador tocou e Edison viu as fotos do jogador com sua esposa, então, perdeu o controle (RIC MAIS, 2019b).

Para o delegado da Polícia Civil, Amadeu Trevisan, a hipótese do estupro está descartada. Como estava com 13,4 decigramas de álcool no sangue, Daniel não tinha condições de realizar qualquer estupro. Segundo ele, o jogador estava apenas deitado na cama (VEJA, 2019b). Informações apuradas pela Imprensa revelaram que Allana comemorou o aniversário com mais de 300 pessoas, que beberam cerca de 140 litros (garrafas) de vodca (RIC MAIS, 2019b).

No dia 29 de novembro de 2018, a Justiça decretou a prisão preventiva de 6 dos 7 acusados: Edison Brittes Júnior por homicídio triplamente qualificado, ocultação de cadáver, corrupção de menor, fraude processual e coação no curso do processo; Cristiana Brittes por homicídio qualificado por motivo torpe, coação do curso de processo, fraude processual e corrupção de menor; Allana Brittes por coação no curso do processo, fraude processual e corrupção de menor. Eduardo da Silva por homicídio triplamente qualificado, ocultação de cadáver, fraude processual e corrupção de menor; Ygor King por homicídio triplamente qualificado, ocultação de cadáver, fraude processual e corrupção de menor e David Willian da Silva por homicídio triplamente 
qualificado, ocultação de cadáver, fraude processual, corrupção de menor e denunciação caluniosa. Dos sete envolvidos, Evellyn Brisola Perusso, acusada de denunciação caluniosa e falso testemunho é a única pessoa que não foi presa preventivamente (WOLF, 2019).

\section{O DISCURSO COLETIVO DO CONEXÃO REPÓRTER}

Nos quadros abaixo constam 10 comentários das categorias Allana e Crime, que foram tabuladas e analisadas, já na categoria Conexão Repórter/Roberto Cabrini, foram incluídos os 7 comentários que apareceram durante a tabulação. As ideias centrais estão em negrito. O quadro número 1 traz a opinião dos internautas sobre Allana Brittes após a sua participação no programa. O quadro número dois, dá exemplos sobre quem são os grandes culpados: o ex-jogador Daniel ou a família Brittes ou ambos. No último quadro aparece o que o público pensa a respeito do Conexão Repórter e do jornalista Roberto Cabrini. Para uma melhor compreensão, erros de grafia escritos pelos internautas foram corrigidos.

Quadro 1 - Exemplos Allana

\begin{tabular}{|c|c|c|c|}
\hline & Sexo & Comentário (ideia central em negrito) & Positivo/Negativo \\
\hline 1 & Masculino & $\begin{array}{c}\text { Se o Daniel as conhecessem sem maquiagem } \\
\text { estaria vivo... }\end{array}$ & Negativo \\
\hline 2 & Indefinido & $\begin{array}{l}\text { Ela tem } 18 \text { anos? parece ter uns } 30 . \\
\text { Psicopata }\end{array}$ & Negativo \\
\hline 3 & Feminino & $\begin{array}{l}\text { Essa menina tem problema mental! } \\
\text { Falando que o cara mereceu e procurou isso! nada } \\
\text { justifica }\end{array}$ & Negativo \\
\hline 4 & Feminino & $\begin{array}{l}\text { Egoísta! o cara foi torturado e morto, e ela só } \\
\text { queria a vida (fútil) dela de volta... }\end{array}$ & Negativo \\
\hline 5 & Feminino & $\begin{array}{l}\text { Lá no shopping estava todo mundo feliz depois } \\
\text { do crime. Mentirosa. }\end{array}$ & Negativo \\
\hline 6 & Feminino & $\begin{array}{l}\text { Dissimulada igual a Suzane Richthofen (quando } \\
\text { deu entrevista para o fantástico e até fingiu choro) }\end{array}$ & Negativo \\
\hline 7 & Feminino & $\begin{array}{l}\text { A vida dela acabou, e ela tá toda montada na } \\
\text { maquiagem se tivesse acabado mesmo nem } \\
\text { ânimo pra passar um batom ela teria. }\end{array}$ & Negativo \\
\hline 8 & Feminino & ter 35 anos & Negativo \\
\hline 9 & Feminino & $\begin{array}{c}\text { Foi uma morte cruel, torturas horríveis. Essa } \\
\text { menina e a família são capazes de qualquer coisa. } \\
\text { Dissimulada, mentirosa e egoísta. }\end{array}$ & Negativo \\
\hline 10 & Feminino & $\begin{array}{l}\text { Gente do céu!!! Acho que essa menina está } \\
\text { mentindo até na idade }\end{array}$ & Negativo \\
\hline
\end{tabular}

Fonte: Elaborado pelos autores de acordo com Lefreve; Lefreve (2006) 
Quadro 2 - Exemplos Crime

\begin{tabular}{|c|c|c|c|}
\hline & Sexo & Comentário (ideia central em negrito) & Culpados \\
\hline 1 & Feminino & $\begin{array}{c}\text { "Ela fala que a pior sensação foi deixar a mãe na } \\
\text { prisão" imagina pra mãe do jogador q nunca } \\
\text { mais vai poder ver filho, já ela basta ir ao presídio } \\
\text { pra ver a mãe dela. }\end{array}$ & Indefinido \\
\hline 2 & Indefinido & $\begin{array}{c}\text { A mistura de bebidas, drogas, dinheiro e a falta } \\
\text { de Deus só gera isso! Infelizmente }\end{array}$ & Indefinido \\
\hline 3 & Masculino & $\begin{array}{c}\text { Não tem inocente nessa história, ele pagou de louco } \\
\text { fazendo graça com mulher casada, porém não } \\
\text { justifica ter sido assassinado da forma que foi. }\end{array}$ & Dois \\
\hline 4 & Feminino & $\begin{array}{l}\text { Deus viu tudo! E um dia cada um dará conta } \\
\text { das suas obras sejam boas ou más. }\end{array}$ & Indefinido \\
\hline 5 & Masculino & Morto não fala. Essa é a grande questão! & Indefinido \\
\hline 6 & Masculino & $\begin{array}{l}\text { Quem matou o Daniel? - Meu Pai. Mas a culpa } \\
\text { foi do Daniel. }\end{array}$ & Daniel \\
\hline 7 & Masculino & $\begin{array}{l}\text { Meu, a mulher bebeu demais e queria das o } \\
\text { rabo, o cara foi corno e não aguentou o chifre. }\end{array}$ & Brittes \\
\hline 8 & Masculino & $\begin{array}{l}\text { Eu acho que ele comia as duas, aí o cornão } \\
\text { pegou e deu ruim pra o jogador. }\end{array}$ & Indefinido \\
\hline 9 & Feminino & $\begin{array}{l}\text { Na minha opinião a história é a seguinte: O Daniel } \\
\text { foi no quarto da Cristiana e passou a tirar fotos } \\
\text { com ela. Ela acordou e viu ele com ela pensando q } \\
\text { ele iria estuprar e passa a gritar, todos entendem } \\
\text { que o Daniel a queria estuprar, e o matam sem } \\
\text { deixa-lo explicar, simples assim. }\end{array}$ & Indefinido \\
\hline 10 & Feminino & $\begin{array}{l}\text { Bom, Daniel como todo jogador gosta de pegar } \\
\text { geral né, então nessa dia deve ter se sentido atraído } \\
\text { pela Cristina, e esperou um melhor momento que } \\
\text { foi justamente aquele, de quando ela foi para o } \\
\text { quarto, o Daniel alcoolizado e para divulgar no } \\
\text { grupo de WhatsApp deitou na cama e começou a } \\
\text { fazer selfies, então acho quando ele agarrou a } \\
\text { mulher e ela começou a gritar e nessa deu tudo } \\
\text { errado, o que começou com uma brincadeira } \\
\text { terminou em crime brutal. }\end{array}$ & Indefinido \\
\hline
\end{tabular}


Quadro 3 - Exemplos Conexão Repórter/Roberto Cabrini

\begin{tabular}{|c|c|c|c|}
\hline & Sexo & Comentário (ideia central em negrito) & Positivo / Negativo \\
\hline 1 & Masculino & $\begin{array}{c}\text { Roberto Cabrini você tem que entrevistas a } \\
\text { Flodelis... }\end{array}$ & Positivo \\
\hline 2 & Masculino & $\begin{array}{c}\text { Lei número de um assassino: Nunca dê uma } \\
\text { entrevista ao Cabrini. Vocês só vão piorar as } \\
\text { coisas. }\end{array}$ & Positivo \\
\hline 3 & Feminino & $\begin{array}{c}\text { Cabrini, o melhor repórter investigativo, até } \\
\text { um inocente gagueja olhando pra ele... }\end{array}$ & Positivo \\
\hline 4 & Masculino & $\begin{array}{c}\text { Di:53 Roberto Cabriniel? } \\
\text { Se passaram quase três segundos pra ela } \\
\text { responder à pergunta do repórter e ainda } \\
\text { ficou com os zoião de lula assustada. }\end{array}$ & Positivo \\
\hline 5 & Feminino & $\begin{array}{c}\text { Sinto preguiça de entrevista com criminosos } \\
\text { mentirosos, mas me desperto com Cabrini } \\
\text { fazendo eles cair em contradições }\end{array}$ & Positivo \\
\hline 6 & Feminino & $\begin{array}{c}\text { Não sei se a chamo de mimada ou dissimulada! } \\
\text { Por essa reportagem você merecia voltar a } \\
\text { prisão! }\end{array}$ & Positivo \\
\hline & Masculino & $\begin{array}{r}\text { Cabrini parece minha mulher quando } \\
\text { pergunta alguma coisa quando demoro pra } \\
\text { chegar, mal respondo e já vem outra } \\
\text { pergunta. }\end{array}$ & Positivo \\
\hline
\end{tabular}

Fonte: Elaborado pelos autores de acordo com Lefreve; Lefreve (2006)

\subsection{Primeira leitura}

Dos 100 comentários, $37 \%$ falaram sobre a Allana, $46 \%$ sobre o crime e $7 \%$ sobre o programa. Os $10 \%$ restantes não puderam ser classificados em nenhum desses três aspectos, sendo excluídos desta análise.

Na classificação "Conexão Repórter/Roberto Cabrini”, todos internautas que se posicionaram de forma escrita, aprovaram o programa, sendo 57\% homens e $43 \%$ mulheres. Dos 37 comentários sobre a "Allana", 100\% falaram negativamente e opinaram a favor da sua culpa. No total foram: $19 \%$ homens, $75 \%$ mulheres e $6 \%$ não puderam ser identificados.

Na classificação “Crime”, 52\% são mulheres, 39\% homens e 9\% não puderam ser identificados. Quase a metade dos internautas (45\%) colocaram a culpa do caso Daniel nos Brittes, $17 \%$ acredita que o maior culpado foi o jogador Daniel, $9 \%$ acredita 
que a culpa está nos dois lados e $28 \%$ não deixa claro a sua posição. As porcentagens foram arredondadas para facilitar a compreensão dos dados.

\subsection{Segunda leitura}

O primeiro passo da segunda análise consistiu em examinar de forma individual cada comentário, nesta pesquisa, também chamado de expressão chave, e, em seguida separar as ideias centrais de cada texto. Esses excertos foram organizados e corrigidos para uma leitura satisfatória.

O segundo passo foi redigir o Discurso do Sujeito Coletivo de cada uma das três categorias, juntando sinergicamente os pontos de vista presentes nas ideias centrais de cada comentário ou expressão chave. Desse modo, construiu-se os Discursos Coletivos, individuais para cada categoria. Na descrição abaixo, diferente da primeira leitura, foram colocadas todas as ideias centrais retiradas de cada comentário.

\section{Allana}

\section{$\mathrm{S}=$ Sujeito - Ideia Central}

S 1 - Se o Daniel as conhecesse sem maquiagem estaria vivo...

\section{S 2 - Psicopata.}

S 3 - Essa menina tem problema mental!

S 4 - o cara foi torturado e morto, e ela só queria a vida (fútil) dela de volta...

S 5 - Lá no shopping estava todo mundo feliz depois do crime.

S 6 - Dissimulada igual a Suzane Richthofen.

S 7- A vida dela acabou, e ela tá toda montada na maquiagem se tivesse acabado mesmo nem ânimo pra passar um batom ela teria.

S 8 - "Eu era uma adolescente normal" parece ter 35 anos

S 9 - Dissimulada, mentirosa e egoísta.

S 10 - Acho que essa menina está mentindo até na idade.

S 11 -. Pior é saber que ela não tem um pingo de arrependimento.

S 12 - Além de dissimulada é burra.

S 13 - Começou a maioridade atrás das grades!

S 14 - Só gagueja e não fala nada de útil.

S 15 - Que pensamento é esse? É doentio! 
S 16 - Essa tem o SELO RICHTOFEN de qualidade.

S 17 - Só vê o lado dela e dos pais, essa Barbie bisturizada.

S 18 - Fia, nos diga o que você faz para gente não fazer também e ficar assim tão acabada.

S 19 - dissimulada ainda teve coragem de ligar pra mãe do Daniel

S 20 - Ela está gordinha. Cara de bolacha.

S 21 - Essa menina me parece que continua mentindo.

S 22 - Tomara que eles nunca tenham paz na consciência.

S 23 - Se tivesse justiça nesse brasil essa coisa ia estar presa.

S 24 - Só falta dizer que Daniel é culpado por tudo e eles são inocentes

S 25 - Se contradiz toda a todo tempo.

S 26 - Parece que na cadeia a comida é boa.

S 27 -. Isso é a culpa na consciência que a deixa mais velha.

S 28 - Alguém prende essa mulher de novo.

S 29 - Simplesmente assassina, fria e calculista.

S 30 - Com cabelo arrumado, maquiada, piercings, unhas feitas, bem vestida, poxa, tá com a vida acabada assim?

S 31 - Todos são cruéis.

S 32 - Ela tem só 18 anos? Olhando pra ela dá pra dizer que tem uns 35 ou mais.

S 33 - Caiu em contradição várias vezes

\section{S 34 - GAGUEJOU MUITO NA ENTREVISTA, SERA QUE MENTIU KKKKKK}

S 35 - Eu nunca fiquei com ele: e o vídeo que aparece ela transando com ele no banheiro

S 36 - Jogar toda a culpa nele é fácil né tá morto não pode se defender!

S 37 - Ela fala como se matar alguém fosse justificável

Discurso sobre a Allana: Ela tem só 18 anos? Olhando pra ela dá pra dizer que tem uns 35 ou mais. Isso é a culpa na consciência que a deixa mais velha. Acho que essa menina está mentindo até na idade. "Eu era uma adolescente normal" parece ter 35 anos. Pior é saber que ela não tem um pingo de arrependimento. Dissimulada, mentirosa e egoísta. Ela fala como se matar alguém fosse justificável. Psicopata. Jogar toda a culpa nele é fácil né, tá morto não pode se defender! Só falta dizer que Daniel é culpado por tudo e eles são inocentes. Se tivesse justiça nesse brasil essa coisa ia estar 
presa. Tomara que eles nunca tenham paz na consciência. Parece que na cadeia a comida é boa. Ela está gordinha. Cara de bolacha. Que pensamento é esse? É doentio! Essa tem o SELO RICHTOFEN de qualidade. Só gagueja e não fala nada de útil. Além de dissimulada é burra.

\section{Crime}

\section{S= Sujeito - Ideia Central}

S 1 - Imagina pra mãe do jogador que nunca mais vai poder ver filho

S 2 - A mistura de bebidas, drogas, dinheiro e a falta de Deus só gera isso!

S 3 - Ele pagou de louco fazendo graça com mulher casada, porém não justifica ter sido assassinado

S 4 - Deus viu tudo! E um dia cada um dará conta das suas obras sejam boas ou más.

S 5 - Morto não fala. Essa é a grande questão!

S 6 - Quem matou o Daniel? - Meu Pai. Mas a culpa foi do Daniel.

S 7 - A mulher bebeu demais e queria dar o rabo, o cara foi corno e não aguentou chifre.

S 8 - Eu acho que ele comia as duas, aí o cornão pegou e deu ruim pra o jogador.

S 9 - Todos entendem que o Daniel a queria estuprar, e o matam sem deixá-lo explicar, simples assim.

S 10 - O que começou com uma brincadeira terminou em crime brutal.

S 11 - O Daniel também vacilou.

S 12 - Deixaram mãe e filha cúmplices na mesma cela?

S 13 - Antes tivesse ido ver a filhinha... não estaria morto

S 14 - Nada justifica tirar a vida de alguém.

S 15 - Ninguém presta nessa história.

S 16 - Essa história está toda muito mal contada.

S 17 - Se não tivesse feito a burrice que fez a festa tinha terminado em paz.

S 18 - Duas safadas exibicionistas, o narcisismo em alta entre os três.

S 19 - Se Daniel desrespeitou a mãe dela, o pai deveria chamar a Polícia e não matá-lo.

S 20 - Todos são culpados.

S 21 - Não há desculpa pra um crime bárbaro desse.

S 22 - Mentira, o jogador pegou a filha e a mãe.

S 23 - Justiça fraca! 
S 24 - É muito fácil só acusar o finado Daniel.

S 25 - Essa família sim, merece apodrecer na cadeia.

S 26 - Se isso não é crime eu tô doido.

S 27 - Ela queria a vida dela e a família de volta! Então né a mãe e a filha do jogador TAMBÉM!

S 28 - Assistia TV na prisão, é o fim dos tempos.

S 29 - O SOFRIMENTO É CONSEQUÊNCIA DE ERROS.

S 30 - "Só por que ele tem dinheiro, achou que podia fazer tudo, e as coisas não são assim"

S 31 - Tem que pegar essas piranhas e fazer o mesmo que fizeram com o Daniel.

S 32 - O crime foi bárbaro com requinte de crueldade...

S 33 - Mandou áudio falando o que fez.... procurou tanto que achou.

S 34 - Vidas destruídas e o diabo batendo palmas.

S 35 - Fosse um homem e pegasse um engraçadinho desses eu fazia ele comer o próprio pênis.

S 36 - Acho engraçado que esse povo só acredita nesses jogadores. Bruno, Daniel, Neymar.

S 37 - Era só ligar para a polícia vir prender ele e pronto!

S 38 - Eles merecem pagar por tudo que fizeram!

S 39 - Justiça com as próprias mãos... fala sério

S 40 - Nada justifica a morte, mas eu fico pensando que se fosse meu pai vendo a cena com a filha ou esposa faria o mesmo.

S 41 - Sua mãe vai ficar muito tempo na cadeia.

S 42 - Foi daí que a Najila surgiu.

S 43 - Imagina sua esposa ou marido dormindo e você pega em flagrante a mesma cena... com certeza daria uma tunda bem dada

S 44 - O PAI DELA NÃO É NINGUÉM NA FILA DO PÃO, É UM MONSTRO.

S 45 - Teve relações com a mulher do próximo o resultado é morte.

S 46 - Os Brites são todos bandidos.

Discurso sobre o Crime: Todos são culpados. O Daniel também vacilou. Ele pagou de louco fazendo graça com mulher casada, porém não justifica ter sido 
assassinado. Se não tivesse feito a burrice que fez, a festa tinha terminado em paz. Acho engraçado que esse povo só acredita nesses jogadores. Bruno, Daniel, Neymar. Teve relações com a mulher do próximo o resultado é morte. Mandou áudio falando o que fez... procurou tanto que achou. Fosse um homem e pegasse um engraçadinho desses eu faria ele comer o próprio pênis. Essa família sim, merece apodrecer na cadeia. Nada justifica tirar a vida de alguém. Era só ligar para a polícia vir prender ele e pronto! Sua mãe vai ficar muito tempo na cadeia. Justiça fraca! Tem que pegar essas piranhas e fazer o mesmo que fizeram com o Daniel. É muito fácil só acusar o finado Daniel.

\section{Conexão Repórter/Roberto Cabrini}

\section{S= Sujeito - Ideia Central}

S 1 - Roberto Cabrini você tem que entrevistar a Flordelis...

S 2 - Lei número de um assassino: Nunca dê uma entrevista ao Cabrini. Vocês só vão piorar as coisas.

S 3 - Cabrini, o melhor repórter investigativo, até um inocente gagueja olhando pra ele...

S 4 - *Alana quem matou o Daniel? Se passaram quase três segundos pra ela responder à pergunta do repórter e ainda ficou com os zoião de lula assustada.

S 5 - Sinto preguiça de entrevista com criminosos mentirosos, mas me desperto com Cabrini fazendo eles cair em contradições.

S 6 - Por essa reportagem você merecia voltar a prisão!

S 7 - Cabrini parece minha mulher quando pergunta alguma coisa quando demoro pra chegar, mal respondo e já vem outra pergunta.

\section{Discurso sobre o Conexão Repórter/Roberto Cabrini:}

Lei número de um assassino: nunca dê uma entrevista ao Cabrini. Vocês só vão piorar as coisas. Cabrini parece minha mulher quando pergunta alguma coisa quando demoro pra chegar, mal respondo e já vem outra pergunta. Cabrini, o melhor repórter investigativo, até um inocente gagueja olhando pra ele... *Alana quem matou o Daniel? Se passaram quase três segundos pra ela responder à pergunta do repórter e ainda ficou com os "zoião" de lula assustada. Sinto preguiça de entrevista com criminosos 
mentirosos, mas me desperto com Cabrini fazendo eles cair em contradições. Roberto Cabrini você tem que entrevistar a Flordelis.

\subsection{Análise dos Discursos do Sujeito Coletivo}

Num primeiro olhar dos dados é possível identificar que a maioria dos internautas que escreveram sobre o programa Conexão Repórter, culpa os Brittes (cerca de 45\%), representados pela figura de Allana durante o programa. Esse movimento acompanha o caso desde a primeira versão sobre o crime, contada por Allana, que foi desmentida por ela mesma mais tarde. Isso parece ter reverberado nos comentários do programa, inclusive sobre como a imagem física da Allana é vista pelos internautas.

É possível encontrar comentários irônicos sobre o fato de a entrevistada afirmar ter 18 anos e na percepção do espectador, ela teria 35 ou mais, como se estivesse mentindo até na idade. Também se observa comentários associando a culpa do assassinato a um possível envelhecimento precoce. O suposto vídeo de Cristiana Brittes transando com Daniel foi citado e parece corroborar com essa imagem de mentirosa.

No discurso sobre o Conexão Repórter/Roberto Cabrini, aos olhos do público, a experiência e a técnica de Roberto Cabrini deixaram evidentes as contradições da fala da Allana. Nos comentários elogiosos à Cabrini e ao Conexão Repórter, os internautas disseram que ele é o melhor repórter investigativo, ou seja, o público considera que o jornalismo do Conexão Repórter é de alta qualidade.

Essa idolatria se torna mais evidente ao perceber que todos os 90 comentários analisados, não foi encontrada nenhuma crítica direcionada ao repórter, programa ou emissora. Um comentário ainda pede para que o Conexão Repórter faça um programa com a cantora, pastora e deputada carioca, Flordelis, que é acusada de ter planejado a morte do marido.

Para o público, na entrevista da "Allana", a única coisa que faltou ela falar foi que a culpa toda é do jogador. Mesmo que a maioria condene os Brittes veementemente, ainda existem os que acreditam na versão contada por Allana para Cabrini no Conexão Repórter e admitem que, talvez, fizessem a mesma coisa na situação de Edison Brittes. Um comentário ainda pontua sarcasticamente que a versão de Daniel teria mais apoio popular devido a sua profissão e ainda o compara com o caso Bruno e Neymar. Esses argumentos se encontram no discurso dos internautas sobre o "Crime". 
Para os que culpam os dois lados, o real problema foi a reação desproporcional. Aos olhos deles, chamar a polícia e tomar as devidas providências legais seria a melhor solução. Ainda existem os que acreditam no ditado popular "olho por olho e dente por dente", ou seja, simplesmente deveriam mutilar os órgãos genitais dos Brittes, ainda vivos, e assassiná-lo, sem direito de defesa.

A coleta desses comentários foi feita no canal oficial do Conexão Repórter no YouTube. Isso mostra que as plataformas digitais têm o poder de ativar o "pensamento" do telespectador sobre um determinado tema abordado num programa de TV, que geralmente é exibido uma única vez, permitindo que o receptor expressar a sua posição sobre o assunto em questão. Além disso, no YouTube, o programa pode ser assistido várias vezes e ficar disponível no acervo online por tempo indeterminado. Enfim, por meio dos comentários foi possível ter uma amostra do que pensam os brasileiros sobre o assassinato do jogador Daniel.

\section{CONSIDERAÇÕES}

Para o público, os grandes culpados são os Brittes, 45\% acreditam nisso, contra $17 \%$ que colocam culpa do assassinato no próprio Daniel e $9 \%$ que acreditam que a culpa pelo crime está nos dois lados. Mesmo sem olhar os números, fica claro o ódio que os internautas sentem pelos acusados. Ao observar as falas na categoria Allana, verifica-se palavras e conotações repetidas, porém, a mais presente é a de mentirosa. Essa imagem de mentirosa instigou as pessoas a fazerem críticas mais fortes nos seus comentários.

Para os internautas que opinaram no canal do SBT no YouTube, a moça mentiu sobre o assassinato, do qual ela fez parte. Por isso, começaram a associar esse comportamento a distúrbios mentais, como a psicopatia, mas também a casos que chocaram a sociedade brasileira, como o caso Richthofen, acontecido na cidade de São Paulo, em 2002. Alguns ainda usam o mesmo artifício para culpar jogador, comparando o caso Daniel com o caso do goleiro Bruno, ocorrido em 2010, na região metropolitana de Belo Horizonte, em que o futebolista planejou a morte de Eliza Samúdio, por conta de uma gravidez indesejada. 
Acredita-se que parte disso vem dela mesmo, por ter contado uma versão mentirosa e admitido essa mentira mais tarde. Ou seja, ela já teria um histórico para os espectadores se apoiarem. E, ao olhar o discurso dos internautas sobre o “Conexão Repórter/ Roberto Cabrini”, em que o trabalho do repórter foi elogiado de maneira unânime, percebe-se que Allana tentou "limpar a sua barra" na entrevista, mas acabou afundando ainda mais.

Para os telespectadores, ao encurralar Allana durante a entrevista e a fazer gaguejar, o repórter conseguiu deixar evidente as mentiras contadas. Entretanto, um dos internautas que chamou Allana de mentirosa, se apoiou em um vídeo falso, em que, supostamente Daniel estaria transando com Cristiana Brittes. Esses fatores dão margem para acreditar que as pessoas já estavam predispostas a destilar ódio sobre os Brittes devido a notícias anteriormente divulgadas sem a checagem dos fatos.

Nesse caso, a entrevista do Cabrini não foi o único fator a influenciar esse quesito. Porém, a ausência total de críticas e esse pedido dos internautas por mais entrevistas, mostram que o programa e o repórter gozam de plena credibilidade com o público.

Ficou claro que os internautas gostam de se posicionar a respeito de assuntos polêmicos. Além disso, apenas 7\% dos comentários retirados do YouTube falavam sobre o programa em si, dessa forma, acredita-se que o grande chamariz é o tema escolhido e a "entrevista exclusiva", fatores que impulsionam a audiência do Conexão Repórter. Em suma, conclui-se que os comentários dos internautas fizeram um linchamento público da Allana e de seus pais, inclusive, se pudessem "fariam justiça" com as próprias mãos, reclamaram dos benefícios que lei dá aos acusados de um crime e enalteceram a habilidade do jornalista Roberto Cabrini, na hora de entrevistar, pessoas acusadas de cometerem delitos.

\section{REFERÊNCIAS}

BOTTA, E. et al. A trajetória de Daniel: seis clubes em seis anos, lesão crônica e morte trágica. Disponível em: https://globoesporte.globo.com/sp/temesporte/futebol/noticia/a-trajetoria-de-daniel-seis-clubes-em-seis-anos-lesao-grave-emorte-tragica.ghtml. Acesso em: 04 jun. 2020. 
BRITTES, Allana. Allana Fala: completo Conexão Repórter (12/08/19). [Entrevista concedida a] Roberto Cabrini. YouTube. Agosto, 2019. Disponível em:

https://www.YouTube.com/watch?v=wCXMJ2fmt6k. Acesso em: 29 ago. 2019.

ESTADÃO DE MINAS. Brasil tem 230 mi de smartphones em uso. Disponível em: https://www.em.com.br/app/noticia/economia/2019/04/26/internas_economia,10 49125/brasil-tem-230-mi-de-smartphones-em-uso.shtml .Acesso: 13 nov. 2019.

FIGUEIREDO, Marília Z.A, CHIARI, Brasília M, DE GOULART Bárbara N. G. Discurso do Sujeito Coletivo: uma breve introdução à ferramenta de pesquisa qualiquantitativa. Distúrb. Comun, São Paulo, v. 25, n. 1, p. 129-136, abril, 2013 Disponível em: http://revistas.pucsp.br/index.php/dic/article/viewFile/14931/11139. Acesso em: 13 nov. 2019.

LEFEVRE, Fernando, LEFEVRE, Ana Maria Cavalcanti. O sujeito coletivo que fala. Interface Comunic, Saúde, Educ, v. 10, n. 20, p. 517-24, jul/dez 2006. Disponível em: http://www.scielo.br/pdf/icse/v10n20/17.pdf. Acesso em: 13 nov. 2019.

MEMÓRIA GLOBO. Roberto Cabrini. Disponível em:

http://memoriaglobo.globo.com/perfis/talentos/roberto-cabrini/trajetoria.htm. Acesso em: 21 ago. 2019.

NEGROPONTE, Nicholas. Vida Digital. São Paulo: Companhia das Letras, 1995.

OBSERVATÓRIO DA IMPRENSA. Como os jovens estão mudando o consumo de notícias. ed. 843, v. 20, n. 1081, 24 mar. 2015. Disponível em:

http://observatoriodaimprensa.com.br/monitor-da-

imprensa/_ed843_como_os_jovens_estao_mudando_o_consumo_de_noticias/.Acess o: 13 nov. 2019.

RIC MAIS. Allana Brittes postou fotos com o jogador Daniel depois do crime. https://ricmais.com.br/noticias/seguranca/allana-brittes-postou-fotos-com-o-jogadordaniel-depois-do-crimel. Acesso em: 28 ago. 2019b.

RIC MAIS. Caso Daniel fotos: veja imagens marcantes da investigação do crime. Disponível em: https://ricmais.com.br/noticias/seguranca/caso-daniel-fotos-vejaimagens-marcantes-da-investigacao-do-crimel. Acesso em: 28 ago. 2019a.

SBT. Canal do Conexão Repórter no YouTube atinge marca de 1 milhão de inscritos. Disponível em: https://www.sbt.com.br/jornalismo/conexaoreporter/noticia/128794-canal-do-conexao-reporter-no-YouTube-atinge-marca-de-1milhao-de-inscritos. Acesso em: 21 ago. 2019.

SOUZA, Carlos Aronchi de. Gêneros e formatos na televisão brasileira. 2.ed. São Paulo: Summus, 2015. 
VEJA. Caso Daniel: delegado descarta suposta tentativa de estupro. Disponível em: https://veja.abril.com.br/placar/caso-daniel-delegado-descarta-suposta-tentativa-deestupro/. Acesso em: 28 ago. 2019b.

VEJA. Caso Daniel: o que se sabe sobre a morte brutal do jogador. Disponível em: https://veja.abril.com.br/placar/caso-daniel-o-que-se-sabe-sobre-a-morte-do-jogadorno-parana/ .Acesso em: 28 ago. 2019a.

WOLF, Carolina. Caso Daniel: Justiça decreta prisão preventiva de seis réus envolvidos na morte do jogador. Disponível em: https://g1.globo.com/pr/parana/noticia/2018/11/29/casodaniel-justica-decreta-prisao-preventiva-de-seis-reus-envolvidos-na-morte-dojogador.ghtml .Acesso em: 28 ago. 2019. 